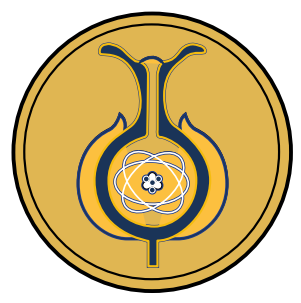

\title{
Excess Mortality Data Analysis of COVID-19 Infections and Fatalities in Ecuador
}

Análisis de datos de exceso de mortalidad por infecciones y muertes por COVID-19 en Ecuador

Análise de dados sobre o excesso de mortalidade por infecções e mortes pela COVID-19 no Equador

Theofilos Toulkeridis $^{1,2}$ Esteban Ortiz-Prado $^{3}$, Jamileth Chunga-Moran $^{4}$, Marco Heredia-R $^{5,6}$, Alexis Debut

Received: Oct/15/2021 • Accepted: Dec/12/2021 • Published: Jan/31/2022

\section{Abstract (10)}

The global COVID-19 pandemic has shocked the world. Since the virus gave rise to health problems and often ended in deaths, the count of the contagion and the deceased has been an open issue. Such statistics are vital for every nation and even every city or district and suburb as these numbers decide the level of intervention and the subsequent reduction of its given spread. Worldwide data show a mortality rate of around two percent prior to successful vaccination campaigns. However, Ecuador's statistical data indicate an abnormal amount of excess mortality, which is officially denied in each of the studied countries. These numbers have been projected on a monthly basis and exceed up to $300 \%$ of the official COVID-19 deaths. In particular, the average mortality rate in Ecuador, prior to and close to the pandemic, has been about $6083.4 \pm 234.6$, while in the worst month during the sanitary crisis, deaths piled up to 21,000 people, and only 1180 were recognized as deceased by COVID-19. The reasons are widespread but based on an insufficient financed health sector, political incompetence, lack of leadership, and a long-lasting economic crisis. Therefore, premature endings of confinements or lockdowns have contributed to an accelerated contagion and seem to even counteract the vaccination phase, in middle 2021, shortly before excess mortality ceased completely.

Keywords: COVID-19; excess mortality; health crisis; data analysis; Ecuador

\footnotetext{
Theofilos Toulkeridis, \ ttoulkeridis@espe.edu.ec, (1D https://orcid.org/0000-0003-1903-7914

Esteban Ortiz-Prado, \ e.ortizprado@gmail.com, (10) https://orcid.org/0000-0002-1895-7498

Jamileth Chunga-Moran, $\bowtie$ jamileth.chungam@ug.edu.ec, (D) https://orcid.org/0000-0001-6835-5308

Marco Heredia-R, \mageher@gmail.com, (D) https://orcid.org/0000-0002-6039-3411

Alexis Debut, $\bowtie$ apdebut@espe.edu.ec, (i) https://orcid.org/0000-0002-8269-7619

1 Universidad de las Fuerzas Armadas ESPE, Sangolquí, Ecuador

2 Universidad de Especialidades turísticas UDET, Quito, Ecuador

3 OneHealth Global Research Group, Universidad de las Américas, Quito, Ecuador

4 Universidad de Guayaquil, Guayaquil, Ecuador

5 Centro de Innovación en Tecnología para el Desarrollo, Universidad Politécnica de Madrid, Madrid, Spain

6 Facultad de Ciencias Agropecuarias, Universidad Técnica Estatal de Quevedo (UTEQ), Quevedo, Ecuador.
} 


\section{Resumen}

La pandemia mundial de COVID-19 ha conmocionado al mundo. Dado que el virus dio lugar a problemas de salud y, a menudo, terminó en muertes, el recuento del contagio y de fallecimientos ha sido un tema abierto. Estas estadísticas son vitales para cada nación e incluso para cada ciudad o distrito y suburbio, ya que estos números deciden el nivel de intervención y la consiguiente reducción de su extensión dada. Los datos mundiales indican una tasa de mortalidad de alrededor del dos por ciento antes de campañas de vacunación exitosas. Sin embargo, los datos estadísticos de Ecuador indican una cantidad anormal de exceso de mortalidad, que oficialmente se niega en cada uno de los países estudiados. Estas cifras se han proyectado mensualmente y superan hasta el $300 \%$ de las muertes oficiales por COVID-19. En particular, en Ecuador la tasa de mortalidad promedio antes y cerca de la pandemia ha sido de alrededor de 6083,4 $\pm 234,6$, mientras que en el peor mes de la crisis sanitaria, las muertes ascendieron a 21 mil personas, pero solo se reconocieron 1180 como personas fallecidas por COVID-19 o con este. Las razones son generalizadas, pero se basan en un sector de salud insuficientemente financiado, incompetencia política, falta de liderazgo y una crisis económica de larga duración. Por lo tanto, las terminaciones prematuras de los confinamientos 0 encierros han contribuido a un contagio acelerado y parecen incluso contrarrestar la fase de vacunación, a mediados de 2021, poco antes de que el exceso de mortalidad cesara por completo.

Palabras clave: COVID-19; exceso de mortalidad; crisis de salud; análisis de los datos; Ecuador

\section{Resumo (1D)}

A pandemia global COVID-19 chocou o mundo. Como o vírus levou a problemas de saúde e, muitas vezes, terminou em mortes, a contagem de infecções e óbitos tem sido um tema aberto. Essas estatísticas são vitais para cada nação e até mesmo para cada cidade ou distrito e subúrbio, pois esses números decidem o nível de intervenção e a consequente redução de sua extensão. Dados globais indicam uma taxa de mortalidade de cerca de $2 \%$ antes de campanhas de vacinação bem sucedidas. No entanto, dados estatísticos do Equador indicam uma quantidade anormal de excesso de mortalidade, que é oficialmente negada em cada um dos países estudados. Esses números foram projetados mensalmente e excedem até $300 \%$ das mortes oficiais pela COVID-19. Em particular, no Equador, a taxa média de mortalidade antes e perto da pandemia foi de cerca de 6.083,4 $\pm 234,6$, enquanto no pior mês da crise sanitária, as mortes foram de 21.000 pessoas, mas apenas 1.180 foram reconhecidas como pessoas mortas pela COVID-19 ou com ela. As razões são generalizadas, porém se baseiam em um setor de saúde subfinanciado, incompetência política, falta de liderança e uma crise econômica de longa duração. Portanto, os términos prematuros de confinamentos ou fechamentos têm contribuído para o contágio acelerado e até parecem neutralizar a fase de vacinação, em meados de 2021, pouco antes de 0 excesso de mortalidade cessar completamente.

Palavras-chave: COVID-19; mortalidade em excesso; crise de saúde; análise de dados; Equador.

\section{Introduction}

A respiratory disease, also known as the COVID-19, has turned into a pandemic that has rapidly spread around the world.
The latest figures from early December 2021 show more than 270 million cases and over 5.32 million deaths officially reported worldwide (Hopkins, 2021; Worldometer, 2021). Infections with the COVID-19 virus 
have been detected in every human group or gender. However, men are more likely to be affected than women, being this more lethal for the elderly and those with previous health conditions, including obesity, hypertension, cancer, diabetes, or any other pulmonary or cardiac preconditions (Adams et al., 2020; Zhang et al., 2021; Jinjarak et al., 2020). The predominant transmission of the virus and its new variants is through exposure to respiratory droplets and aerosols that can be projected at different distances (Wang et al., 2021). Such aerosols and droplets appear with an estimated diameter of 5 to 10 micrometers $(\mu \mathrm{m})$, and also through droplet nuclei, whose diameter is less than 5 micrometer (OMS, 2014; Smieszek et al., 2019). Social, cultural, or environmental circumstances have been responsible for the unusual higher spreading of the virus (Chakraborty et al., 2020; Sharifi et al., 2020; Roberto et al., 2020; Wolf et al., 2020; Lakshmi et al., 2020; Toulkeridis et al., 2020; Toulkeridis et al., 2021). Patient zero is still unknown, but the first appearance of the virus originated from China, either by an indirect contagion from a bat through an unknown mammal to a human or less likely by a laboratory leak presumably by the end of 2019 (Rothan et al., 2020; Zhang et al., 2020; Shahzad et al., 2020; Shi et al., 2021). As such circumstances are still unclear and, as not all infected persons show the mildest symptoms, therefore, the real count of infected and even deceased people has been a challenge for authorities, planning officials, the health sector, and response organizations (Galaitsi et al., 2021; Khan et al., 2021). Based on official accounts, South America represents only $5.5 \%$ of the world population but register $25.6 \%$ of the deceased and some $18.1 \%$ of the infected patients by the COVID-19 (Hopkins, 2021; Worldometer, 2021). Therefore, in the current study, we have chosen to approach to encounter the most real number of infected and deceased people in an area where, on the one hand, the original circumstances are already challenging, such as failing or unfunded health sector, social and political crisis prior to and during the pandemic and, on the other hand, a general long-lasting economic crisis is present, as occurring since several years in Ecuador (Ortiz-Prado \& Fernández-Naranjo, 2020). We may be able to bring some transparency on the official rates of excess mortality based on the regular mortality rates, even if not labeled as demise by COVID-19 by a simple data analysis of the death rates.

\section{Data and Methods}

The official patient zero of COVID-19 appeared in Ecuador in February 2020. This first patient arrived from Italy and most likely has been responsible for contagions in the Province of Guayas, prior to several more outbreaks in the city of Guayaquil and a variety of further towns. As patient treatment within families and later in hospitals, as well as handling of health security, remained initially unknown to the corresponding treating personnel, the contagion and death rate rose, and based on similar worldwide circumstances, Ecuador's governmental authorities closed its borders and declared a strict lockdown by March 16, 2020, which lasted some two months (Garzon-Chavez et al., 2021). Prior to such declaration, Ecuador had been already in a delicate economic situation due to a low oil price, fatal policies, as well as consequences of a variety of past natural disasters areas (Anderson et al., 2016; Jin et al., 2016; Toulkeridis et al., 2017; Toulkeridis et al., 2016; Toulkeridis et al., 2015; Toulkeridis et al., 2016; Rodriguez et al., 2017; Wolff 
et al., 2018; Hidrobo et al., 2019; Schodt et al., 2019; Beyers et al., 2020). Since, a variety of outbreaks created a first hot spot and rapid contamination of a high number of people with a corresponding high death rate in Guayaquil and the province of Guayas due to social and political circumstances.

All fatalities of all kinds of origins have been registered in Ecuador by its National Institute of Statistics and Census (INEC) for a few years on a daily basis (Instituto Nacional de Estadistica y Censo, 2021). Data of the ministry of health of all registered cases of COVID-19, either of contagion or deaths by the virus, are transmitted to the presidency, the press, and the official accountants of diseases such as the John Hopkins Research Center, besides several others. The data of all fatalities, including the official deceased patients of COVID-19, are listed in Table 1. Hereby, the average mortality for 26 months prior to the first case of COVID-19 (January 2018-February 2020) is about 6083.4 \pm 234.6 persons (Table 1).

Table 1

Ecuador's total mortality rates between 2018 and 2021 based on Instituto

Nacional de Estadística y Censos. 2021.

\begin{tabular}{lcccc}
\hline & $\mathbf{2 0 1 8}$ & $\mathbf{2 0 1 9}$ & $\mathbf{2 0 2 0}$ & $\mathbf{2 0 2 1}$ \\
\hline January & 6696 & 6706 & 6699 & 8454 \\
February & 5751 & 5930 & 6057 & 7652 \\
March & 6057 & 6570 & 10030 & 10241 \\
April & 5778 & 6159 & 20977 & 11976 \\
May & 5883 & 5960 & 10111 & 10340 \\
June & 5758 & 5891 & 8997 & 7660 \\
July & 5977 & 6078 & 10845 & 7301 \\
August & 6104 & 6245 & 10055 & 6560 \\
September & 5814 & 6194 & 7991 & 6124 \\
October & 5938 & 5976 & 7557 & 5971 \\
November & 5799 & 6010 & 7321 & 6137 \\
December & 6427 & 5712 & 7137 & T.B.D. \\
Total & $\mathbf{7 1 9 8 2}$ & $\mathbf{7 3 4 3 1}$ & $\mathbf{1 1 3 7 7 7}$ & $\mathbf{7 6 3 0 8}$ \\
\hline
\end{tabular}

Note: derived from Instituto Nacional de Estadística y Censos. 2021.

\section{Results and Discussion}

There has been a clear and long-lasting excess mortality in Ecuador since the beginning of the pandemic, which ends by the mid-end of 2021 (Table 1). The COVID-19 pandemic has started to alter the regular mortality rates, and an end is just recently observed, certainly due to vaccination that has begun in February of 2021. The occurrence of excess mortality frequently appears during usually short periods of time, such as in the aftermath of a strong earthquake, an outbreak of seasonal diseases, or other unusual but given circumstances like armed conflicts (Ansart et al., 2009; Vandoros et al., 2020; Luy., 2003; Wheatcroft et al., 1984; Walsh et al., 2017; De Waal et al., 1989). Although clear excess mortality has existed in Ecuador since the declaration of the pandemic, however, when calculating the average mortality rates prior to the pandemic and adding the official death rate by the COVID-19 virus, a high discrepancy exists (Table 2). When observing the reported fatalities of April 2020, the non-reported mortality numbers are eleven times higher than those of the official provided by the ministry of health. On average, during the entire period of the pandemic, there are some $300 \%$ excess mortality compared to the official COVID-19 mortality rate. There are exceptional months where excess mortality combined with the death toll by COVID-19 is within the average mortality rate, like for May and October of 2020, while mortality rates below the mentioned combined death toll are below average since August 2021, also interpreted as the end of the excess mortality in Ecuador.

Based on an average death toll of around 9,020 monthly (March 2020-November 2021), the excess mortality toll exceeds 
Table 2

Excess mortality rates of Ecuador Data of February to November corresponding to 2020 and 2021 based on Hopkins, 2021; Worldometer, 2021; Instituto Nacional de Estadistica y Censo, 2021.

\begin{tabular}{lcccccc}
\hline & \multicolumn{2}{c}{$\begin{array}{c}\text { Excess Mortality } \\
\text { (EM) }\end{array}$} & \multicolumn{2}{c}{$\begin{array}{c}\text { Off. Covid Mortality } \\
\text { (OCM) }\end{array}$} & \multicolumn{2}{c}{$\begin{array}{c}\text { EM and OCM } \\
\text { (DEO) }\end{array}$} \\
\hline January & $\mathbf{2 0 2 0}$ & $\mathbf{2 0 2 1}$ & $\mathbf{2 0 2 0}$ & $\mathbf{2 0 2 1}$ & $\mathbf{2 0 2 0}$ & $\mathbf{2 0 2 1}$ \\
February & N.A. & 2371 & N.A. & 813 & N.A. & 1558 \\
March & N.A. & 1569 & N.A. & 949 & N.A. & 620 \\
April & 3947 & 4158 & 116 & 1020 & 3831 & 3138 \\
May & 14894 & 5893 & 1180 & 1779 & 13714 & 4114 \\
June & 4028 & 4257 & 3847 & 1941 & 181 & 2316 \\
July & 2914 & 1577 & 1828 & 971 & 1086 & 606 \\
August & 4762 & 1218 & 1835 & 654 & 2927 & 564 \\
September & 3972 & 477 & 1327 & 625 & 2645 & -148 \\
October & 1908 & 41 & 1105 & 505 & 803 & -464 \\
November & 1474 & -112 & 1312 & 157 & 162 & -269 \\
December & 1238 & 54 & 783 & 295 & 455 & -241 \\
Total & 1054 & T.B.D. & 565 & T.B.D. & 489 & T.B.D. \\
\hline
\end{tabular}

Note: derived from research.

almost 62,000 persons, although the official numbers of deceased people by COVID-19 realized by the national ministry of health do not reach more than 23,607 victims. Therefore, we have observed that we lack an explanation of some 38,087 deceased who are not registered as COVID-19 victims until the end of September of 2021. The first explanations given by the ministry of health have been the lack of access of cancer patients to hospitals during the lockdown who died at home. But at the same time, fatal traffic accidents and work-related fatalities were not registered due to the same circumstances. Nonetheless, the most plausible explanation for such a high death toll is that most of the almost 62,000 deceased people, above the average death toll, have been victims by COVID-19.

If the excess mortality has reached almost 62,000 citizens from March 2020 to November 2021, while the official mortality by COVID-19 has been slightly more than 23,000 by the end of November 2021, then we assume that the contagion is also much higher than the officially stated, i.e., around 511,000 for the same period of time. When considering that in all official worldwide statistics there has been a contagion/mortality rate of $2.16 \%$ (by June 30, 2021), then, the calculated number of infected people in Ecuador will be of at least 2,833,000 citizens by the end of November 2021. This corresponds to more than $15.75 \%$ of the total population of the country. Additionally, based on these calculations of the excess mortality, the deaths per 1 million citizens would reach a rate of about 3434: this is just worldwide lower only to one country being Peru with 5950 (Fig. 1) (Hopkins, 2021; Worldometer, 2021). Based on such calculations and the aforementioned circumstances of different ways of contagion, it is a matter of simple arithmetic prior to a successful nationwide vaccination to preview that the health of the entire country's population will be compromised in a variety of degrees. 


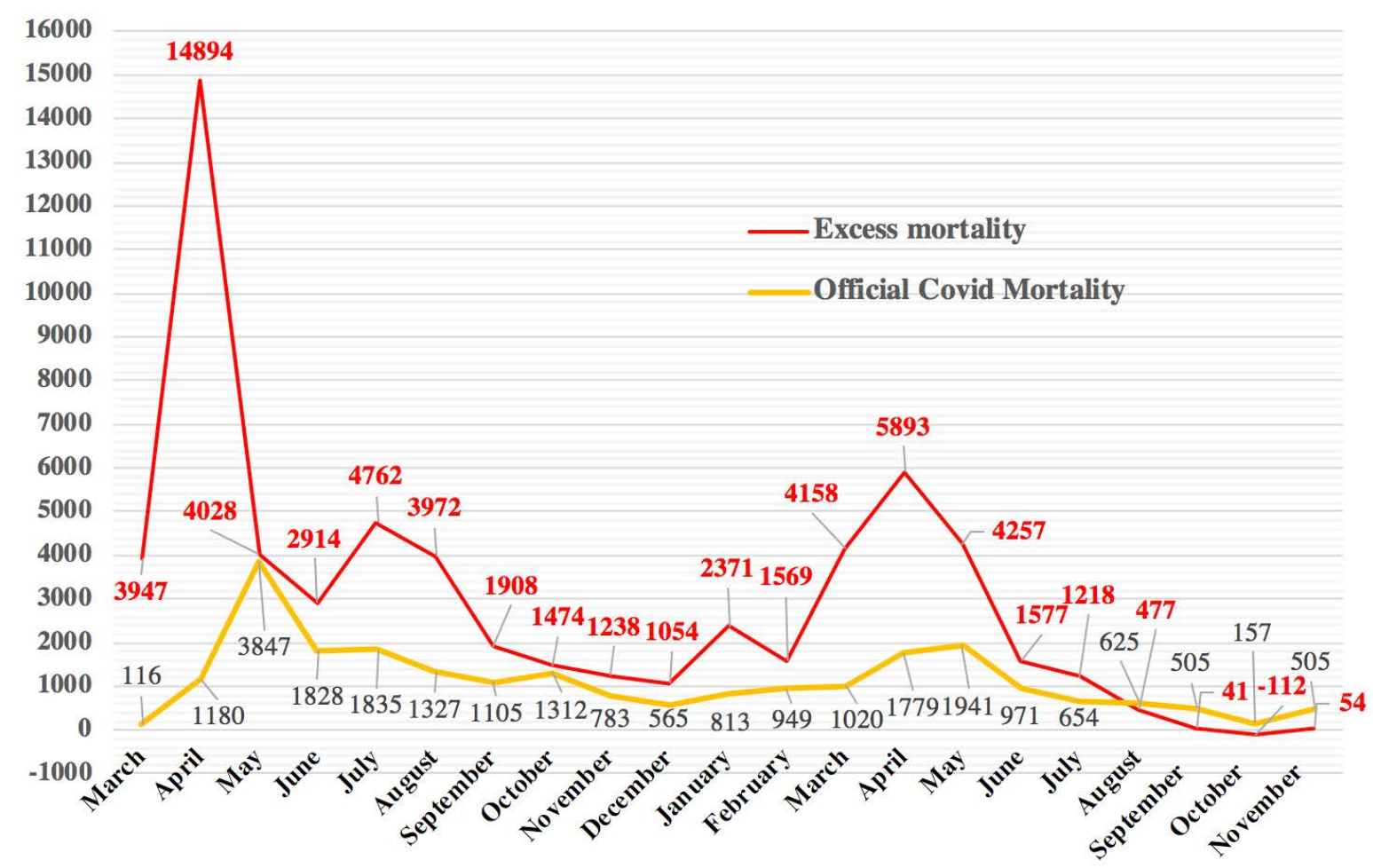

Figure 1. Comparison of official COVID Mortality (OCM) and excess mortality (EM) in Ecuador from February 2020 up to November 2021.

Note: derived from research.

As it seems, South America is a hot spot of deaths by the COVID-19, based on fatal interpretations, premature, late or not given political decisions, lack of governmental leadership, a long-lasting economic crisis, corruption in high social-economic levels, in combination to unfunded health services, late and slow vaccination, as well as predominantly undisciplined public during the pandemic (Patiño et al., 2020; Burki et al., 2020; Herrera et al., 2021; Ortega et al., 2020; Fonseca et al., 2020; Joathan et al., 2021; Cardona-Ospina et al., 2021). Based even on official statistics about contagion and fatalities of the COVID-19 pandemic, which, as demonstrated for the Ecuadorian case, are highly underrated, still, the outcoming numbers are of great concern. South America has a population of some 434 million people, which corresponds to only
$5.5 \%$ of the world population, but the whole continent registers $25.6 \%$ of the deceased because of Covid, more than a fourth of the world fatalities. The contagion is reflected by an amount of almost 3.4 million which represents some $18.1 \%$ of the worldwide infected by the COVID-19 (Hopkins, 2021; Worldometer, 2021). It seems that Ecuador is passing the end of the third wave of contagion and corresponding fatalities (Fig. 1).

Based on the aforementioned, the most plausible recommendation to the authorities and the corresponding public would be an accelerated vaccination process, a strong and lasting lockdown, as well as an improvement of health facilities and services, prior to the impact of a fourth even deadlier wave due to new mutants such as the delta variation (Knack et al., 2020; Harvey et al., 2021; 


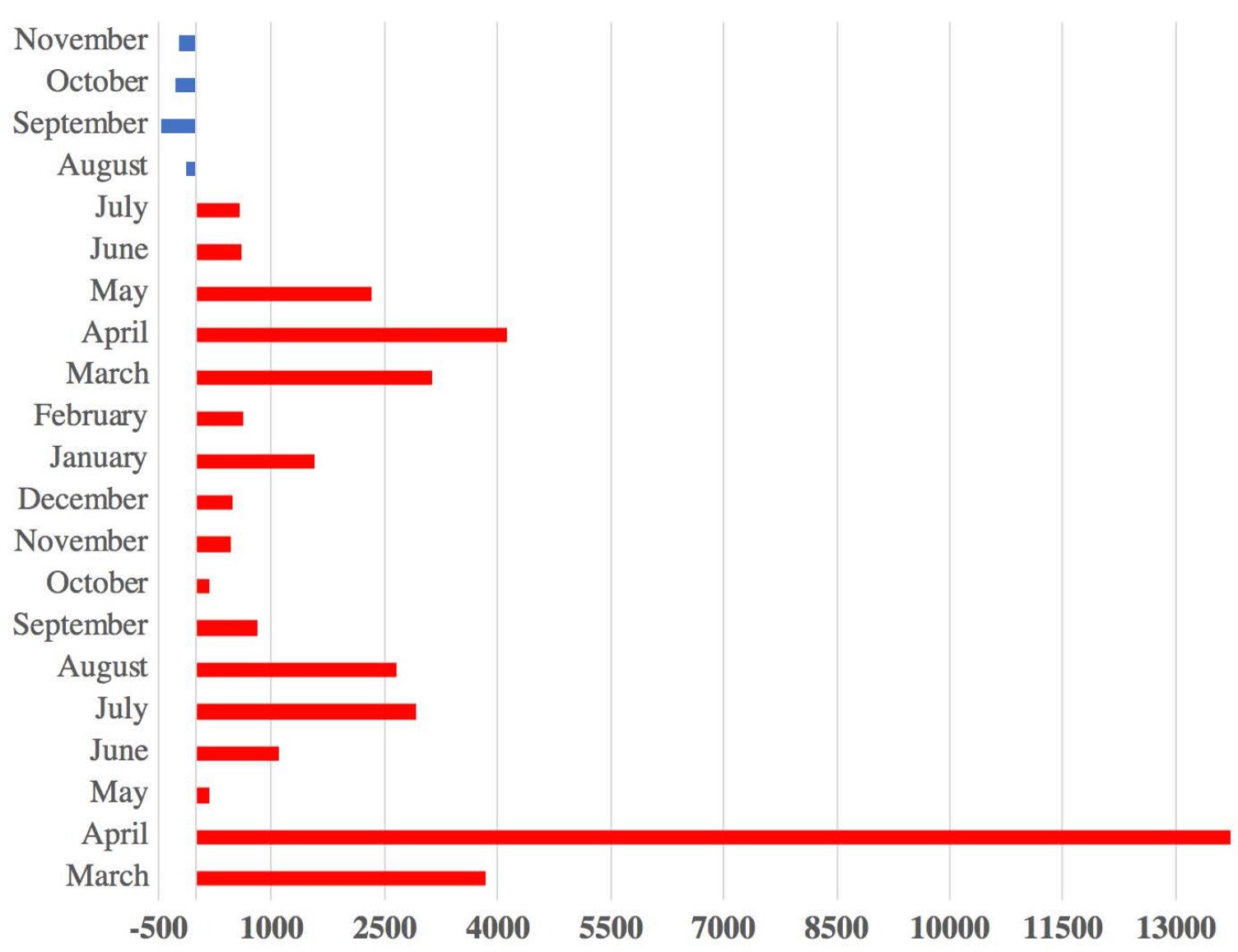

Figure 2. Unreported COVID-19 fatalities in Ecuador from February 2020 (lower part of the graphic) up to November 2021 (upper part of the graphic) based on table 2. Note: derived from research.

Sahoo et al., 2020). Such activities certainly need political leadership and strict control of the implementation, which may also have some more indirect benefits for the society and the environment (Pacheco et al., 2020; Ortiz-Prado et al., 2021; Zalakeviciute et al., 2020). Unfortunately, the recent political decisions point out contrarily towards more openings of businesses and academic institutions rather to a needed strong lockdown.

\section{Conclusions}

COVID-19, which is transmitted in a variety of forms, is a deadly virus with a death rate of some $2.16 \%$ in respect to the infected number of people.

Ecuador has been so far the second-strongest affected country worldwide by the global COVID-19 pandemic when counting deaths per million citizens based on the calculated excess mortality rates.

Based on the high impact of the COVID-19 in Ecuador, an accelerated vaccination process is needed with a simultaneous strong lockdown, rather than further openings of state institutions and private businesses. 


\section{Conflict of Interest}

The authors declare no competing interests.

\section{Author contribution statement}

The total contribution percentage for the conceptualization, preparation, and correction of this paper was as follows: T.T 60 \%., E.O.P $10 \%$, J.C.M. $10 \%$, M.H.R. 10\% and A.D. $10 \%$.

\section{Data availability statement}

The data supporting the results of this study will be made available by the corresponding author, [TT], upon reasonable request.

\section{References}

Adams, M. L., Katz, D. L. \& Grandpre, J. (2020). Population-based estimates of chronic conditions affecting risk for complications from coronavirus disease, United States. Emerging infectious diseases, 26(8), 1831.

Anderson, A. (2016). Dollarization: A case study of Ecuador. Journal of Economics and Development Studies, June, 4(2), 56-60.

Ansart, S., Pelat, C., Boelle, P. Y., Carrat, F., Flahault, A. \& Valleron, A. J. (2009). Mortality burden of the 1918-1919 influenza pandemic in Europe. Influenza and other respiratory viruses, 3(3), 99-106.

Beyers, C., \& Nicholls, E. (2020). Government through Inaction: The Venezuelan Migratory Crisis in Ecuador. Journal of Latin American Studies, 52(3), 633-657.

Burki, T. (2020). COVID-19 in Latin America. The Lancet Infectious Diseases, 20(5), 547-548.

Cardona-Ospina, J. A., Arteaga-Livias, K., Villamil-Gómez, W. E., Pérez-Díaz, C. E., Katterine Bonilla-Aldana, D., Mondragon-Cardona, Á. \& Paniz-Mondolfi, A. (2021). Dengue and COVID-9, overlapping epidemics? An analysis from Colombia. Journal of Medical Virology, 93(1), 522-527.
Chakraborty, I., \& Maity, P. (2020). COVID-19 outbreak: Migration, effects on society, global environment and prevention. Science of the Total Environment, 728, 138882.

De Waal, A. (1989). Famine mortality: a case study of Darfur, Sudan 1984-5. Population Studies, 43(1), 5-24.

Fonseca, B. D. P., Albuquerque, P. C., \& Zicker, F. (2020). Neglected tropical diseases in Brazil: lack of correlation between disease burden, research funding and output. Tropical Medicine \& International Health, 25(11), 1373-1384.

Galaitsi, S. E., Cegan, J. C., Volk, K., Joyner, M., Trump, B. D., \& Linkov, I. (2021). The challenges of data usage for the United States' COVID-19 response. International Journal of Information Management, 59, 102352.

Garzon-Chavez, D., Romero-Alvarez, D., Bonifaz, M., Gaviria, J., Mero, D., Gunsha, N. \& Reyes, J., (2021). Adapting for the COVID-19 pandemic in Ecuador, a characterization of hospital strategies and patients. PloS one, 16(5), e0251295.

Harvey, A., Kattuman, P. \& Thamotheram, C. (2021). Tracking the mutant: Forecasting and nowcasting Covid-19 in the UK in 2021. National Institute Economic Review, 256, 110-126.

Herrera, D., Altamirano, C. T., \& Gaus, D. (2021). COVID-19 in Ecuador: Imported Control Strategies without Context in a Challenged Healthcare System. The American Journal of Tropical Medicine and Hygiene, 104(2), 414.

Hidrobo, J. A. (2019). Power and industrialization in Ecuador. Routledge.

Instituto Nacional de Estadística y Censos. (2021). Población demográfica. INEC. https://www.ecuadorencifras.gob.ec/ censo-de-poblacion-y-vivienda/

Jin, S. J., Lim, S. Y., \& Yoo, S. H. (2016). Causal relationship between oil consumption and economic growth in Ecuador. Energy Sources, Part B: Economics, Planning, and Policy, 11(9), 782-787.

Jinjarak, Y., Ahmed, R., Nair-Desai, S., Xin, W. \& Aizenman, J. (2020). Accounting for global COVID-19 diffusion patterns, January-April 2020. Economics of disasters and climate change, 4(3), 515-559.

Joathan, Í., Medrado, A., \& Medeiros, T. (2021). Brazil: More than just a little flu. In Political Communication and COVID-19 (pp. 220230). Routledge. 
John Hopkins Coronavirus Research Center. (28 of October 2021). https://coronavirus.jhu.edu/

Khan, M., Adil, S. F., Alkhathlan, H. Z., Tahir, M. N., Saif, S., Khan, M., \& Khan, S. T. (2021). COVID-19: a global challenge with old history, epidemiology and progress so far. Molecules, $26(1), 39$.

Knack, R. S., Hanada, T., \& Knack, R. S. (2020). Variant CCR5 Delta 32 and The Possible Protective Factor Against COVID-19. Biomedical Journal of Scientific \& Technical Research, 32(4), 25246-25247.

Lakshmi Priyadarsini, S., \& Suresh, M. (2020). Factors influencing the epidemiological characteristics of pandemic COVID 19: A TISM approach. International Journal of Healthcare Management, 13(2), 89-98.

Luy, M. (2003). Causes of male excess mortality: insights from cloistered populations. $\mathrm{Po}$ pulation and Development Review, 29(4), 647-676.

Organización Mundial de la Salud [OMS]. (2014). Prevención y control de las infecciones respiratorias agudas con tendencia epidémica y pandémica durante la atención sanitaria. OMS. https://www.paho.org/ $\mathrm{hq} / \mathrm{dmdocuments} / 2014 / 2014$-cha-prevencion-control-atencion-sanitaria.pdf

Ortega, F. \& Orsini, M. (2020). Governing COVID-19 without government in Brazil: Ignorance, neoliberal authoritarianism, and the collapse of public health leadership. Global public health, 15(9), 1257-1277.

Ortiz-Prado, E., Simbaña-Rivera, K., Barreno, L. G., Diaz, A. M., Barreto, A., Moyano, C., \& Lowe, R. (2021). Epidemiological, socio-demographic and clinical features of the early phase of the COVID-19 epidemic in Ecuador. PLoS Neglected Tropical Diseases, 15(1), e0008958.

Ortiz-Prado, E., \& Fernández-Naranjo, R. (2020). Impacto de la COVID-19 en el Ecuador: De los datos inexactos a las muertes en exceso. Revista Ecuatoriana de Neurología, 29(2), 8-11.

Pacheco, H., Díaz-López, S., Jarre, E., Pacheco, H., Méndez, W., \& Zamora-Ledezma, E. (2020). NO2 levels after the COVID-19 lockdown in Ecuador: A trade-off between environment and human health. Urban Climate, 34, 100674.
Patiño, A. M., Cantillo-Campos, S., Kearney, A. S., Kivlehan, S. M., \& Maldonado, A. (2020). Emergency Medicine Challenges in Ecuador. Western Journal of Emergency Medicine, 21(6), 284.

Roberto, K. J., Johnson, A. F., \& Rauhaus, B. M. (2020). Stigmatization and prejudice during the COVID-19 pandemic. Administrative Theory \& Praxis, 42(3), 364-378.

Rodriguez, F., Toulkeridis, T., Padilla, O., \& Mato, F. (2017). Economic risk assessment of Cotopaxi volcano Ecuador in case of a future lahar emplacement. Natural Hazards, 85(1), 605-618.

Rothan, H. A., \& Byrareddy, S. N. (2020). The epidemiology and pathogenesis of coronavirus disease (COVID-19) outbreak. Journal of autoimmunity, 109, 102433.

Sahoo, J. P., Mishra, A. P., Behera, L., Nath, S., \& Samal, K. C. (2020). New Mutant COVID-19 Strain (VUI-202012/01)-More Contagious than Current Status. Biotica Research Today, 2(12), 1331-1333.

Schodt, D. W. (2019). Ecuador: an Andean enigma. Routledge.

Shahzad, F., \& Nasim, M. T. (2020). COVID-19: A natural phenomena or laboratory-based origin? Bangladesh Journal of Medical Science, 85-S.

Sharifi, A., \& Khavarian-Garmsir, A. R. (2020). The COVID-19 pandemic: Impacts on cities and major lessons for urban planning, design, and management. Science of The Total Environment, 142391.

Shi, Z. L. (2021). Origins of SARS-CoV-2: Focusing on Science. Infectious Diseases \& Immunity, $1(1), 3$.

Smieszek, T., Lazzari, G., \& Salathé, M. (2019). Assessing the Dynamics and Control of Dropletand Aerosol-Transmitted Influenza Using an Indoor Positioning System. Scientific reports, 9(1), 2185. https://doi.org/10.1038/ s41598-019-38825-y

Toulkeridis, T., \& Zach, I. (2017) Wind directions of volcanic ash-charged clouds in Ecuador Implications for the public and flight safety. Geomatics, Natural Hazards and Risks, 8(2): 242-256.

Toulkeridis, T. (2016). Unexpected results of a seismic hazard evaluation applied to a modern hydroelectric plant in central Ecuador. Journal of Structural Engineering, 43(4), 373-380. 
Toulkeridis, T., Arroyo, C. R., Cruz D’Howitt, M., Debut, A., Vaca, A.V., Cumbal, L., Mato, F., \& Aguilera, E. (2015). Evaluation of the initial stage of the reactivated Cotopaxi volcano - Analysis of the first ejected fine-grained material. Natural Hazards and Earth System Sciences, 3(11), 6947-6976.

Toulkeridis, T., Chunga, K., Rentería, W., Rodriguez, F., Mato, F., Nikolaou, S., Cruz D'Howitt, M., Besenzon, D., Ruiz, H., Parra, H., \& Vera-Grunauer, X. (2017). The 7.8 Mw Earthquake and Tsunami of the 16th April 2016 in Ecuador - Seismic evaluation, geological field survey and economic implications. Science of tsunami hazards, 36, 197-242

Toulkeridis, T., Seqqat, R., Arias, M. T., Salazar-Martínez, R., Ortiz-Prado, E., Chunga, S., \& Debut, A. (2021). Volcanic Ash as a precursor for SARS-CoV-2 infection among susceptible populations in Ecuador: A satellite Imaging and excess mortality-based analysis. Disaster Medicine and Public Health Preparedness, 1-37.

Toulkeridis, T., Seqqat, R., Torres, M., Ortiz-Prado, E., \& Debut, A. (2020). COVID-19 Pandemic in Ecuador: a health disparities perspective. $R e$ vista de Salud Pública de Colombia, 22(3), 1-5.

Vandoros, S. (2020). Excess mortality during the Covid-19 pandemic: Early evidence from England and Wales. Social Science \& Medicine, 258, 113101.

Walsh, D., McCartney, G., Collins, C., Taulbut, M., \& Batty, G. D. (2017). History, politics and vulnerability: explaining excess mortality in Scotland and Glasgow. Public Health, 151, 1-12.
Wang, C. C., Prather, K. A., Sznitman, J., Jimenez, J. L., Lakdawala, S. S., Tufekci, Z., \& Marr, L. C. (2021). Airborne transmission of respiratory viruses. Science, 373(6558), eabd9149.

Wheatcroft, S. G. (1984). A note on Steven Rosefielde's calculations of excess mortality in the USSR, 1929-1949. Soviet Studies, 36(2), 277-281.

Wolf, L. J., Haddock, G., Manstead, A. S., \& Maio, G. R. (2020). The importance of (shared) human values for containing the COVID-19 pandemic. British Journal of Social Psychology, 59(3), 618-627.

Wolff, J. (2018). Ecuador after Correa: the Struggle over the "Citizens' Revolution". Revista de Ciencia Política, 38(2), 281-302.

Worldometer. (29 of October 2021). https://www. worldometers.info/coronavirus/

Zalakeviciute, R., Vasquez, R., Bayas, D., Buenano, A., Mejia, D., Zegarra, R., \& Lamb, B. (2020). Drastic improvements in air quality in Ecuador during the COVID-19 outbreak. Aerosol and Air Quality Research, 20(8), 1783-1792

Zhang, J. Y., Shang, T., Ahn, D., Chen, K., Coté, G., Espinoza, J., \& Klonoff, D. C. (2021). How to best protect people with diabetes from the impact of SARS-CoV-2: Report of the International COVID-19 and Diabetes Summit. Journal of Diabetes Science and Technology, 15(2), 478-514.

Zhang, X., Chen, X., Zhang, Z., Roy, A., \& Shen, Y. (2020). Strategies to trace back the origin of COVID-19. The Journal of infection, 80(6), e39.

\section{(C) $(1 \otimes \Theta$}

Excess Mortality Data Analysis of COVID-19 Infections and Fatalities in Ecuador (Theofilos Toulkeridis • Esteban Ortiz-Prado • Jamileth Chunga-Moran • Marco Heredia-R

- Alexis Debut) Uniciencia is protected by Attribution-NonCommercial-NoDerivs 3.0 Unported (CC BY-NC-ND 3.0) 